\title{
Implementasi Program SADARI pada Siswi Sekolah Menengah Atas di Kota Pontianak
}

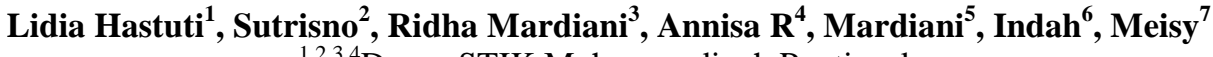 \\ 1,2,3,4 Dosen STIK Muhammadiyah Pontianak \\ 5,6,7 Mahasiswa STIK Muhammadiyah Pontianak \\ Email : lidya_zain@yahoo.com
}

Published: $16 / 06 / 2020$

\begin{abstract}
Cancer is one of the four major diseases in society. And can attack all walks of life without exception and without knowing social status, age or gender. Children, adolescents, and adults have not escaped this deadly attack. But from the data available most women are affected by cancer. Breast cancer still ranks first in new cases and cancer deaths, amounting to $43.3 \%$ and $12.9 \%$. The highest cancer suffered by Indonesian women is breast cancer with an incidence of 26 per 100,000 women. One effort that can be done to prevent breast cancer is to implement a healthy lifestyle and breast self-awareness (BSE). This examination can detect breast cancer early and almost $85 \%$ of lumps in a woman's breast are found by the sufferers themselves. The Care for society program aims to improve adolescent reproductive health through BSE examination as a screening for disease. The implementation of BSE program assistance was carried out for high school students (Muhammadiyah I High School) in Pontianak. Presentation of Information to Teachers and School UKS Officers to periodically inform of BSE and provide direct assistance to students in conducting BSE examination. An increase in average knowledge after being given an explanation of breast cancer in students and skills in BSE examination after being given assistance. BSE Assistance by Health Workers and UKS Officers increases students' knowledge and awareness to conduct BSE examination in an effort to prevent breast cancer events.
\end{abstract}

Keywords: BSE, program implementation, reproductive health, teenager

\begin{abstract}
Abstrak
Kanker adalah salah satu dari empat besar penyakit utama pada masyarakat. Penyakit ini tidak mengenal status sosial, umur juga jenis kelamin. Anak-anak, remaja, dan orang dewasa tak luput dari serangan mematikan ini. Namun dari data yang ada kaum wanita paling banyak terkena kanker. Kanker payudara masih menempati urutan pertama kasus baru dan kematian akibat kanker, yaitu sebesar $43,3 \%$ dan $12,9 \%$. Kanker tertinggi yang di derita wanita Indonesia adalah kanker payudara dengan angka kejadian 26 per 100.000 perempuan. Salah satu upaya yang bisa dilakukan untuk mencegah kanker payudara ini adalah dengan melaksanakan gaya hidup sehat dan melakukan breast self-awareness (Pemeriksaan payudara sendiri/ SADARI). Pemeriksaan ini dapat mendeteksi secara dini kanker payudara dan hampir $85 \%$ benjolan di payudara wanita ditemukan oleh penderita sendiri. Program Care for society bertujuan untuk meningkatkan kesehatan reproduksi remaja melalui pemeriksaan SADARI sebagai skrining terhadap penyakit. Implementasi pendampingan program SADARI dilaksanakan pada siswi sekolah menengah atas (SMA Muhammadiyah I) di Kota Pontianak. Pemaparan Informasi kepada Guru dan Petugas UKS sekolah agar secara berkala menginformasikan Pemeriksaan SADARI dan melakukan pendampingan langsung pada siswi dalam melakukan pemeriksaan SADARI.Terjadi peningkatan rata-rata pengetahuan setelah diberikan penjelasan tentang penyakit kanker payudara pada siswi dan keterampilan dalam pemeriksaan SADARI setelah diberikan pendampingan. Pendampingan SADARI oleh Tenaga kesehatan dan Petugas UKS meningkatkan pengetahuan siswi dan kesadaran untuk melakukan pemeriksaan SADARI dalam upaya preventif terjadinya kejadian kanker Payudara.
\end{abstract}

Kata Kunci: implementasi program, kesehatan reproduksi, remaja, SADARI 


\section{PENDAHULUAN}

Kanker dapat menyerang semua lapisan masyarakat tanpa terkecuali dan tanpa mengenal status sosial, umur juga jenis kelamin. Anak-anak, remaja, dan orang dewasa tak luput dari serangan mematikan ini. Namun dari data yang ada kaum wanita paling banyak terkena kanker (Kartikawati, 2012). WHO mencatat telah terjadi 7,6 juta kematian di seluruh dunia akibat kanker. Dari hasil penelitian membuktikan bahwa kanker payudara baik di Indonesia maupun Amerika Serikat memperlihatkan kecenderungan meningkat dari tahun ke tahun. Kanker payudara sebagai jenis kanker yang paling banyak ditemui pada wanita. Setiap tahun lebih dari 250.000 kasus baru kanker payudara terdiagnosa di Eropa dan kuranglebih 175.000 di Amerika Serikat (Lumban Gaol \& Briani, 2014). Hampir lebih dari 14 juta orang di diagnose mengalami kanker, mayoritas terjadi pada social ekonomi. Tahun 2015, 8.8 juta meninggal karena kanker (WHO, 2017).

Data di Indonesia diperkirakan terdapat 100 penderita baru per 100.000 penduduk setiap tahunnya. Ini berarti dari jumlah 237 juta penduduk, ada sekitar 237.000 penderita kanker baru setiap tahunnya. Kanker tertinggi yang diderita wanita Indonesia adalah kanker payudara dengan angka kejadian 26 per 100.000 perempuan. Kanker payudara menempati urutan pertama pada pasien rawat inap diseluruh Indonesia (16,85\%) disusul kanker leher rahim $(11,78 \%)$. Prevalensi tumor/kanker di Indonesia adalah 1,4 per 1000 penduduk (Kemenkes.RI, 2015). Menurut data Buletin Jendela Data dan Informasi Kesehatan, pada penduduk perempuan kanker payudara masih menempati urutan pertama kasus baru dan kematian akibat kanker, yaitu sebesar 43,3\% dan 12,9\% (Badan Penelitian dan Pengembangan Kesehatan, 2013). Tingginya angka kejadian kanker payudara mengakibatkan tidak sedikit pula penderita kanker payudara yang berujung pada kematian.

Angrainy (2017) menemukan bahwa terdapat hubungan antara pengetahuan, sikap dengan Pemeriksaan payudara sendiri (SADARI) dengan masing-masing $\mathrm{p}$ value 0,007 dan 0,001 . Sejalan dengan penelitian tersebut, penelitian yang dilakukan oleh Tri Viviawati (2014 dalam Angrainy, 2017) dengan judul pengaruh pedidikan kesehatan tentang pemeriksaan SADARI sebagai deteksi dini kanker payudara terhadap pengetahuan dan sikap remaja putrid di SMK N 1 Karang anyar didapatkan hubungan yang signifikan antara pengetahuan remaja putrid dengan pelaksanaan pemeriksaan SADARI dengan pvalue 0,05. SADARI merupakan salah satu upaya untuk mendeteksi terjadinya masalah-masalah pada payudara.

Permasalahan Mitra adalah kurangnya pemahaman dan implikasi masalah kesehatan reproduksi, khususnya pada pengetahuan tentang kanker payudara dan keterampilan dalam melakukan deteksi dini kanker payudara dengan tindakan SADARI. Informasi yang diterima/ diberikan belum memberikan perlindungan (protection) kepada remaja dari hal-hal yang membahayakan kesehatan reproduksi.Penting untuk menyadari bagaimana bentuk normal payudara dan ada tidaknya perubahan dari waktu ke waktu. Dengan deteksi dini payudara banyak wanita berhasil selamat dari kanker payudara.

Tindakan ini sangat penting karena hampir $85 \%$ benjolan di payudara wanita ditemukan oleh penderita sendiri. Skrening SADARI perlu dilakukan bagi remaja putri sebagai upaya pencegahan terjadinya masalah-masalah kesehatan lebih lanjut. Survei pada SMA Muhammadiyah, informasi tentang penyakit-penyakit atau masalah di payudara sangat sedikit. Hal ini menyebabkan kurangnya upaya yang dilakukan oleh remaja putrid untuk memperhatikan masalah penyakit dan 
kesehatan khususnya masalah di sekitar payudara Salah satu upaya yang bias dilakukan untuk mencegah kanker payudara ini adalah dengan melaksanakan gaya hidup sehat dan melakukan breast self-awareness (BSE) atau lebih dikenal dengan nama SADARI.

\section{TARGET DAN LUARAN}

Target dalam kegiatan ini adalah semua siswi SMA Muhammadiyah I Kota Pontianak. Luaran dalam kegiatan ini adalah Peningkatan pemahaman siswi dalam mendeteksi dini penyakit-penyakit pada organ reproduksi khususnya kanker payudara, serta meningkatkan keterampilan siswi dalam melakukan pemeriksaan payudara sendiri (SADARI).

\section{METODE PELAKSANAAN}

Care of society merupakan salah satu program STIK Muhammadiyah Pontianak yang merupakan program kepedulian terhadap permasalahan masyarakat yang merupakan isu lokal, maupun nasional. Program ini mendukung program-program yang dijalankan secara nasional.

Kegiatan pengabdian SADARI dapat dilakukan melalui diskusi, tanya jawab, memberikan leaflet dan demonstrasi pemeriksaan tehnik SADARI serta aplikasi pemeriksaan langsung (Nurfitriani dan Julaecha, 2019). Hal tersebut juga dilakukan dalam pengabdian ini yaitu dengan memberikan penyuluhan kesehatan pada siswi dengan menggunakan metode ceramah, brainstorming dan Tanya jawab, serta melakukan pendampingan pada siswi saat melakukan pratikum pemeriksaan SADARI sebagai upaya deteksi dini kanker payudara. Siswi juga memperoleh media poster sebagai panduan dalam pemeriksaan SADARI di rumah.

\section{HASIL DAN PEMBAHASAN}

Kegiatan ini terintegrasi dengan kegiatan keputrian sekolah yang dilaksanakan bagi siswi SMA
Muhammadiyah I Pontianak dengan total jumlah peserta 364 siswi. Penyuluhan kesehatan dilakukan selama 90 menit. Semua peserta memperhatikan dan menyimak terhadap materi yang telah disampaikan dan belajar dengan menggunakan media poster tentang Pemeriksaan SADARI sebagai panduan untuk pemeriksaan sendiri dirumah. Kemudian berikutnya adalah pendampingan pemeriksaan SADARI pada siswa dan melakukan follow up dengan petugas UKS jika ada temuan kasus. Tidak ada temuan benjolan pada siswi saat melakukan pemeriksaan. Peserta melakukan umpan balik terhadap materi yang diberikan dengan melakukan Tanya jawab pada akhir sesi. Penyuluhan kesehatan dan pendampingan SADARI meningkatkan pengetahuan dan keterampilan siswi dalam mendeteksi masalah di Payudara.

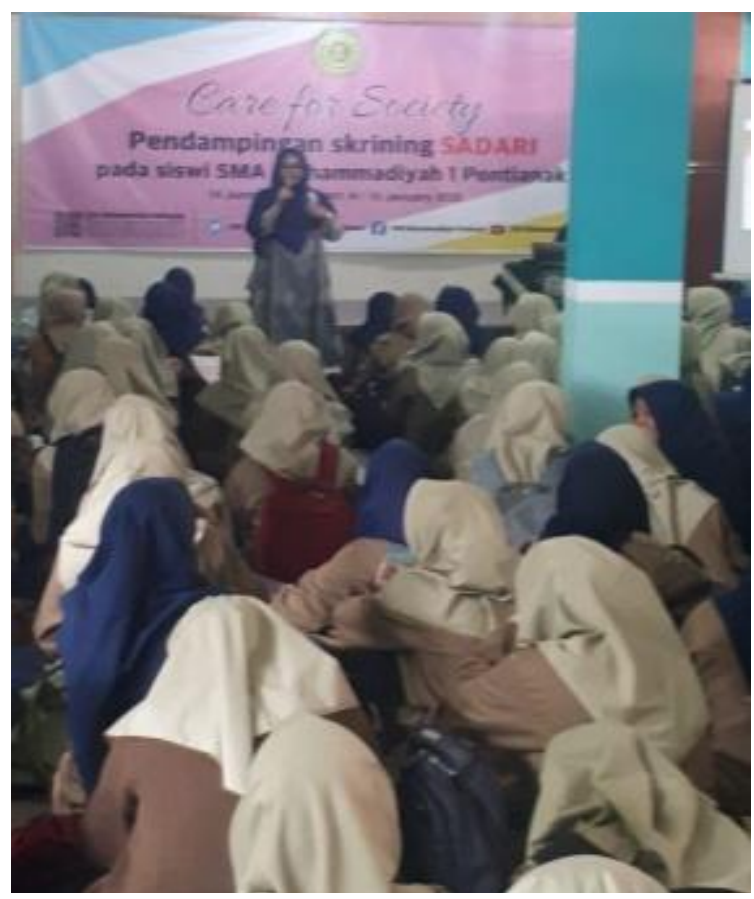

Gambar.1 Penyuluhan dan Pendampingan

SADARI

\section{KESIMPULAN DAN SARAN \\ 1. Kesimpulan}

Kegiatan meningkatkan pemahaman pada siswi SMA Muhammadiyah I tentang 
kanker payudara dan deteksi dini SADARI. Dengan meningkatkan pemahaman siswi akan meningkatkan kewaspadaan dan meningkatkan kesehatan individu khususnya masalah kesehatan reproduksi.

\section{Saran}

Sekolah dapat berkolaborasi dengan tenaga kesehatan di Puskesmas dan Perguruan Tinggi dalam mengembangkan program-program yang terintegrasi dengan program UKS di sekolah untuk meningkatkan kesehatan remaja di SMA.

\section{UCAPAN TERIMA KASIH}

\begin{tabular}{crr}
\multicolumn{2}{c}{ Ucapan terimakasih kami } \\
sampaikan kepada Ketua STIK
\end{tabular} Muhammadiyah, Ketua Pusat Penelitian dan Pengabdian kepada masyarakat, Kepala Sekolah, dan Wakil kepala sekolah bidang Kesiswaan SMA Muhammadiyah I Pontianak, serta Guru-guru dan Petugas UKS sebagai fasilitator dalam kegiatan ini.

\section{DAFTAR PUSTAKA}

Angrainy,R.A., Sugita, S., \&Susilowati, D. (2014). Hubungan pengetahuan sadari dengan minat deteksi dini kanker payudara pada remaja puteri kelas xi di sma n 1 karang dowo klaten. Jurnal Kebidanan Indonesia. Retrieved from http://jurnal.akbidmu.ac.id/index.php/ jurnalmus/article/v iew/43

Badan Penelitian dan Pengembangan Kesehatan. (2013). Riset Kesehatan Dasar (RISKESDAS) 2013. Laporan Nasional 2013, 1-384.

Kartikawati, Erni. (2012). Awas!!! Bahaya Kanker Payudara \& Kanker Serviks (EdisiPertama). Bandung: BukuBaru Kemenkes.RI. (2015). Panduan Nasional Penanganan Kanker Kanker Payudara. Komite Nasional Penanggulangan Kanker (KPKN).
LumbanGaol, H., \&Briani, F. (2014). Kanker Payudara. Kapita Selekta Kedokteran, 230-236.

Nurfitriani dan Julaecha. 2019. Pengenalan Tehnik Sadari Di Rt 15 Kelurahan Buluran Kenali. Jurnal Abdimas Kesehatan. 1(1):35-39. http://dx.doi.org/10.36565/jak.v1i1.16

WHO. (2017). WHO List of priority medical devices for cancer management.Printed by the WHO Document Production Services, Geneva, Switzerland. ISBNISBN 978-92-4-156546-2 